Section Editor

John J. Millichap, MD

\title{
Teaching NeuroImages: \\ Figure of 8
}

The clue to the diagnosis of AMPD2 pontocerebellar hypoplasia (PCH9)

Mariasavina Severino, MD

Figure

\section{Typical figure of 8 midbrain appearance of $\mathrm{PCH} 8$ subtype}

Federico Zara, PhD

Andrea Rossi, MD

Pasquale Striano, MD, $\mathrm{PhD}$

Correspondence to

Dr. Striano:

strianop@gmail.com

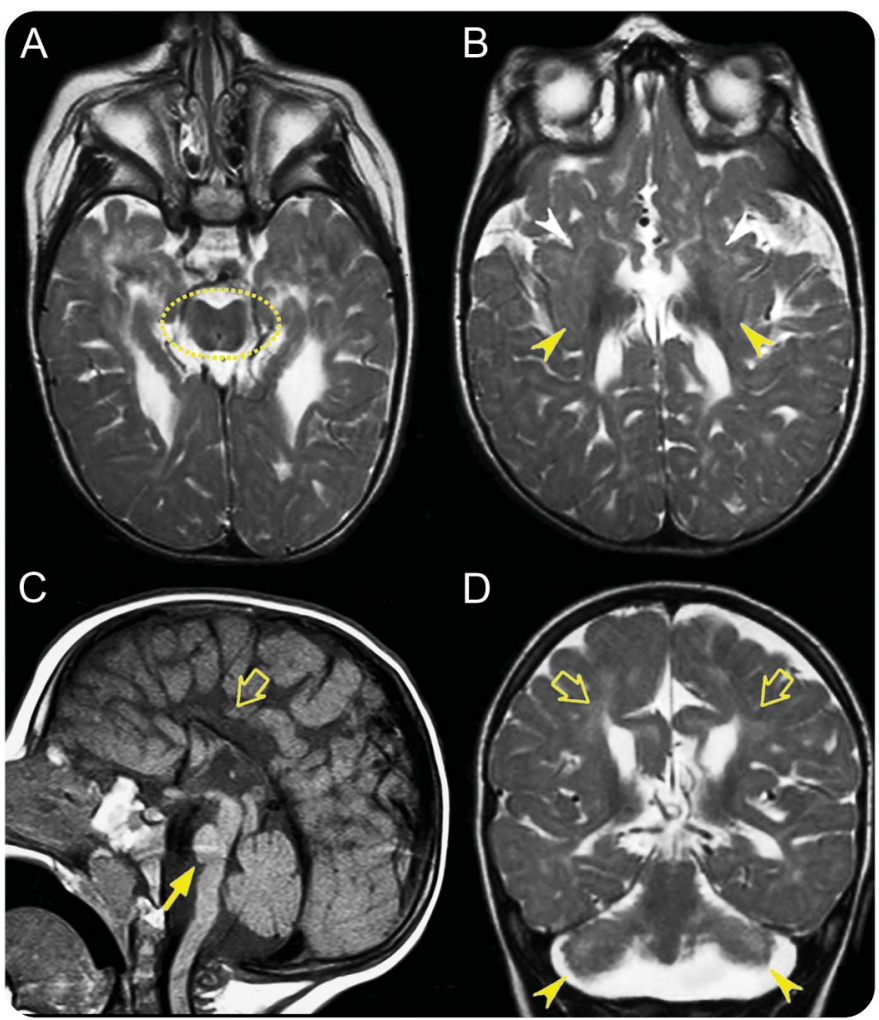

(A, B) Axial T2-weighted images of figure of 8 midbrain appearance (dotted oval), small hyperintense basal ganglia, and hypointense thalami (arrowheads). (C) Sagittal T1-weighted image: small pons (arrow), absent corpus callosum (empty arrow). (D) Coronal T2-weighted image: cerebellar hemispheric atrophy (arrowheads) and periventricular leukoencephalopathy (empty arrows).

A 2-year-old girl, born after uneventful pregnancy from healthy nonconsanguineous parents, presented with failure to thrive, microcephaly, facial dysmorphism, strabismus, nystagmus, axial hypotonia, lower limb spasticity/hyperreflexia, dystonic movements, and no active postures. Since the first months of life, developmental delay without any motor skills acquisition, drug-resistant epilepsy, and progressive spasticity had emerged. Neuroimaging revealed pontocerebellar hypoplasia with the figure of 8 midbrain appearance (figure), a distinctive sign for PCH8 or AMPD2 deficiency. ${ }^{1,2}$ Sanger sequencing of the adenosine monophosphate deaminase 2 enzyme gene (AMPD2) revealed the first compound heterozygous mutation (c.1664C>T; c.1112+1 G>A). The patient died at age 3 years due to respiratory insufficiency.

\section{AUTHOR CONTRIBUTIONS}

Pasquale Striano, Mariasavina Severino: drafting the manuscript. Andrea Rossi, Federico Zara: critical revision. All authors approved the final version.
Download teaching slides: Neurology.org
From the Neuroradiology Unit (M.S., A.R.), Laboratory of Neurogenetics (F.Z.), and Pediatric Neurology and Muscular Diseases Unit, Department of Neurosciences, Rehabilitation, Ophthalmology, Genetics, Maternal and Child Health, University of Genoa (P.S.), Istituto "Giannina Gaslini," Genova, Italy.

Go to Neurology.org for full disclosures. Funding information and disclosures deemed relevant by the authors, if any, are provided at the end of the article. 
STUDY FUNDING

No targeted funding reported.

\section{DISCLOSURE}

The authors report no disclosures relevant to the manuscript. Go to Neurology.org for full disclosures.
REFERENCES

1. Akizu N, Cantagrel V, Schroth J, et al. AMPD2 regulates GTP synthesis and is mutated in a potentially treatable neurodegenerative brainstem disorder. Cell 2013;154:505-517.

2. Marsh AP, Lukic V, Pope K, et al. Complete callosal agenesis, pontocerebellar hypoplasia, and axonal neuropathy due to AMPD2 loss. Neurol Genet 2015;1:e16. 


\section{Neurology}

\section{Teaching NeuroImages: Figure of 8: The clue to the diagnosis of AMPD2 pontocerebellar hypoplasia (PCH9) \\ Mariasavina Severino, Federico Zara, Andrea Rossi, et al. \\ Neurology 2017;89;e172-e173 \\ DOI 10.1212/WNL.0000000000004542}

\section{This information is current as of October 2, 2017}

\section{Updated Information \& Services}

\section{Supplementary Material}

\section{References}

Subspecialty Collections

\section{Permissions \& Licensing}

Reprints including high resolution figures, can be found at: http://n.neurology.org/content/89/14/e172.full

Supplementary material can be found at: http://n.neurology.org/content/suppl/2017/10/02/WNL.0000000000004 542.DC1

This article cites 2 articles, 1 of which you can access for free at: http://n.neurology.org/content/89/14/e172.full\#ref-list-1

This article, along with others on similar topics, appears in the following collection(s):

\section{All Clinical Neurology}

http://n.neurology.org/cgi/collection/all_clinical_neurology

All Genetics

http://n.neurology.org/cgi/collection/all_genetics

\section{All Pediatric}

http://n.neurology.org/cgi/collection/all_pediatric

MRI

http://n.neurology.org/cgi/collection/mri

Information about reproducing this article in parts (figures,tables) or in its entirety can be found online at:

http://www.neurology.org/about/about_the_journal\#permissions

Information about ordering reprints can be found online: http://n.neurology.org/subscribers/advertise

Neurology ${ }^{\circledR}$ is the official journal of the American Academy of Neurology. Published continuously since 1951, it is now a weekly with 48 issues per year. Copyright (O 2017 American Academy of Neurology. All rights reserved. Print ISSN: 0028-3878. Online ISSN: 1526-632X.

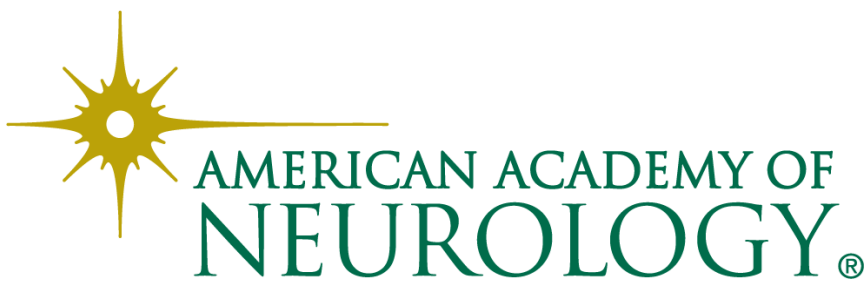

